American Journal of Applied Sciences 7 (8): 1123-1128, 2010

ISSN 1546-9239

(C) 2010 Science Publications

\title{
Effect of Raising the Environmental Awareness on Reducing Kitchen Water Consumption by Jordanian Families Living in Amman City
}

\author{
${ }^{1}$ Damanhouri Mohammad Sai'd, ${ }^{2}$ Ayman S. Mazahreh, ${ }^{3}$ Heba Hammad, \\ ${ }^{4}$ Ali F. Al-Shawabkeh and ${ }^{3}$ Khaled Shaker Al-Saraireh \\ ${ }^{1}$ Department of Basic Sciences, \\ ${ }^{2}$ Department of Applied Sciences, \\ ${ }^{3}$ Department of Education Science, \\ Princes Alia University College, Al-Balqa Applied University, Jordan \\ ${ }^{4}$ Department of Applied Sciences, Faculty of Engineering Technology, \\ Al-Balqa Applied University, Jordan
}

\begin{abstract}
Problem statement: Improper use of water by Jordanian families accombined with acute shortage in water resources. Approach: This study aimed to raise the degree of the environmental awareness regarding the significance of reducing kitchen water consumption of the Jordanian families living in Amman and to provide them with the necessary knowledge and practices about the right practices to reduce water consumption. Results: The results revealed that the average consumption of kitchen water before the environmental awareness about water consumption was $59.5 \mathrm{~L} \mathrm{day}^{-1}$ and after raising the awareness was reduced to $49.8 \mathrm{~L} \mathrm{day}^{-1}$, with an average of $9.7 \mathrm{~L} \mathrm{day}^{-1}$ which is a very vital indicator. The difference in the consumption were found to be more for the families consisting of (1014) members where the average differences was $12-14 \mathrm{~L} \mathrm{day}^{-1}$, but after environmental awareness differences were all statistically significant with all the other groups of family members. The average difference of consumption by family of members aged from (6-9) was (10-39) L daily and it was statistically significant in the family group of (2-5). The family group of (2-5) showed an average difference of 7.25 L daily. However, the family of with members aged between (15-22) years was the best in making use of raising the degree of environmental awareness to preserve water and reduce its consumption. The study also showed that the differences of consumption were more for the family groups of the average of income (601-1000) JD/month. The study also revealed that there is a positive relationship (0.801) regarding the amount of the consumed water and the number of utensils used through the three meals of day after raising the degree of environmental awareness in this study which shows the necessity of education the consumers to reduce the number of utensils, to reduce the amount of lost water out of consumed water. Conclusion: It can be concluded that raising awareness by holding sessions for the families is about water consumption is a reliable method to rationalize their consumption.
\end{abstract}

Key words: Environmental awareness, kitchen water consumption, Jordanian families

\section{INTRODUCTION}

Water is ultimate source of life and due to the enormous demand on this blue gold (Othman, 2008) it's becoming a reason for many regional fights.

It's cirrhotic that from all water that's cornering earth only $5 \%$ is suitable for human consumption (Oliver, 1990). Also not only human needs water for his biological needs, but also he needs it for industry and agriculture that both consume most of the available water.
However, water is becoming a hot issue for researches in terms of water resources, quality, quantity and strategies to find and manage resources as will as the pattern of consumption by the deferent users (an agriculture, industry, house utility and wild life).

Some studies have revealed that for every dollar spent on manufacturing a produce, there are $100 \mathrm{~L}$ of water consumed for such production in the USA while it's reduced to 50 and $151 \mathrm{~L}$ in Germany and Japan respectively (Rosegrant et al., 2002).

Corresponding Author: Ayman S. Mazahreh, Department of Applied Science, Princes Alia University College, Al-Balqa Applied University, P.O. Box 941941, Amman, 11194 Jordan 
Am. J. Applied Sci., 7 (8): 1123-1128, 2010

Table 1: Water consumption-Jordan*

\begin{tabular}{|c|c|c|c|c|c|c|c|c|}
\hline \multirow[b]{2}{*}{ Number } & \multirow[b]{2}{*}{ Year } & \multirow{2}{*}{$\begin{array}{l}\text { Amount of consumed } \\
\text { water for industrial } \\
\text { agriculture, animals } \\
\text { and domestic uses } \mathrm{m} \cdot \mathrm{m}^{3}\end{array}$} & \multirow{2}{*}{$\begin{array}{l}\text { Amount of } \\
\text { consumed water for } \\
\text { domestic uses } \mathrm{m} \cdot \mathrm{m}^{3}\end{array}$} & \multirow{2}{*}{$\begin{array}{l}\text { Percentage of } \\
\text { the consumed water for } \\
\text { domestic uses to the total } \\
\text { amount of the consumed } \\
\text { water in different uses (\%) }\end{array}$} & \multicolumn{2}{|c|}{$\begin{array}{l}\text { Surface water which } \\
\text { consumed in domestic uses }\end{array}$} & \multicolumn{2}{|c|}{$\begin{array}{l}\text { Ground water which } \\
\text { Consumed in domestic uses }\end{array}$} \\
\hline & & & & & Amount & Percentage & Amount & Percentage \\
\hline$\overline{1}$ & 2003 & 810 & 262 & 32.3 & 54.0 & 21.0 & 208 & 79.00 \\
\hline 2 & 2004 & 866 & 281 & 33.6 & 66.0 & 23.0 & 215 & 77.00 \\
\hline 3 & 2005 & 941 & 291 & 30.9 & 75.0 & 26.0 & 216 & 74.00 \\
\hline 4 & 2006 & 925 & 291 & 31.5 & 92.0 & 31.5 & 199 & 68.50 \\
\hline 5 & 2007 & 940 & 294 & 31.3 & 80.0 & 27.0 & 214 & 73.00 \\
\hline 6 & 2008 & 936 & 315 & 33.5 & 87.0 & 23.5 & 228 & 65.00 \\
\hline Average & 6 years & 903 & 289 & 32.20 & 75.7 & 25.3 & 213 & 72.75 \\
\hline
\end{tabular}

*Source: Venot et al. (2006)

Generally the worlds a natural average consumption of an individual is about to $1240 \mathrm{~m}^{3}$ water. However, this amount differs according to country, season and place within same country. Meanwhile this amount is lowered annually about $250 \mathrm{~m}^{3}$ and in Jordan the whole average of individual and consumption doesn't exceed $150 \mathrm{~m}^{3}$. For this reason the Jordanian government has made great effects to preserve and to develop it's limited water resources.

Jordan, up to the recent past, was the tenth country in water shortage according to the international records, but due to local and regional factor, it has become the fourth country.

This is why it became necessary to conduct studies and research in the area of water its uses for farming, industrial, house raising animals in hope that studies will contribute to reduce the extent of water shortage and its effect on the water budget of Jordan.

It can be noticed from Table 1 that water consumption for domestic purpose in Jordan reaches to $32 \%$ out of the total consumed water in the different economical activities. This is a high percentage compared to the advanced countries where this percentage is $13 \%$, even though it is increasing annually reaching $20 \%$ between (2003-2008).

It appears that $75 \%$ of the consumed water for domestic uses is under-ground water. Most of this under-ground water is not revivable.

In addition, the weather of Jordan is dry and it faces the problem of the reduction in annual fall of rain which doesn't exceed $350 \mathrm{ml}$ annually on $90 \%$ out of the total area of Jordan. This surely emphasizes that Jordan is a poor country in its water resources which necessitates the economical use of water.

This is why this study aimed at exploring the effect of raising the degree of the environmental awareness of economical use of water in washing kitchen utensils and dishes.

This study tries to achieve the following objectives: Finding and measuring the effect of raising the environmental awareness on the sample of the study in relation to the significance of water and preserving it.

Finding the rate of the consumed water by the family to wash the food and kitchen utensils before raising the degree of the environmental awareness.

Finding the rate of the consumed water by the family to wash the food and kitchen utensils after raising degree of the environmental awareness.

Finding the effective factors on water consumption to wash the food and kitchen utensils.

Finding the percentage of the saved water which will be the outcome of raising the degree of environmental awareness in washing the food and kitchen utensils.

Many studies world wide have been concerned with water issue. Hadjer et al. (2005) studied the domestic consumption of water and the social conations in (Benin) Africa as annexable of a country with limited water resources. He found that one of the basic limitation of house water consumption is the seasonal and/or the amount of water fall. In his study Hadjer et al. (2005) revealed a negative relationship between water consumption and family size as will as member's age. The study also categorized area's of water house consumption in to hygiene use (30-40\%), kitchen (20$22 \%)$, dish washing (12\%), drinking (7-10\%), clothes washing (2-14\%) car washing (1-6\%) and house and pets $(7 \%)$.

Rose Gram (2006) studied factors affecting water consumption in global level such as rain, temperature and infrastructure. He found that poor infra structure as well as weak water management have resulted in increasing water consumption.

Water consumption pathways in both developing and developed countries can be categorized in to the following:

- $\quad$ Agriculture (62-85\%)

- Industry (5-22\%)

- Domestic area (8\%)

- Wild life (2\%) 
However Tarawneh et al. (2008) (6) revealed five factors that significantly affect water consumption. These factors were the amount of consumption compared to national out put (GDP) pattern of consumption in both product and services, were there, population growth, cultural practices and water quality for farming and the general weather.

The study of Otaki et al. (2008) studied the difference in water consumption in "Chaing Mai" Japan between the raining season and the dry season.

Also it related the average consumption to the total national output, it studied the ways of measuring the consumed water, like the direct measurement of the daily family water mage, the personal interview and that depends on collecting data through receptivity's measurements in subsequent times. It found that when people feel the water scarcity during the dry season lead them to sensible usage of water.

Moreover, the average consumption of water for domestic uses depends on the type of utensils usually used in the kitchen or for washing, bathing and the bathroom, the average of the individual consumption in (Chaing Mai) usually used for all the domestic uses is less than the least amount of the average individual average consumption which reaches daily about $30 \mathrm{~L}$.

The study concluded that the variance at the public awareness regarding the importance of water leads to the variance of water consumption, more specifically in countries that do not provide the right attention to its water resources or the lost water that is usually happened as a result of water distribution.

\section{MATERIALS AND METHODS}

Experiment 1: The degree of environmental awareness was measured using a questionnaire prepared for the sake of this study. Then a series of sessions and workshops were organized to raise the degree of the environmental awareness regarding water usage for the sample of the study. Next a questionnaire was distributed again for the members of the sample. It was found that the degree of the environmental awareness developed to be $78 \%$ whereas it was $28 \%$ before the implementation of the program.

Table 2: The feature of the sample's study

\begin{tabular}{lllll}
\hline & Number & Means & $\begin{array}{l}\text { Standard } \\
\text { deviation }\end{array}$ & $\begin{array}{l}\text { Level of } \\
\text { significance }\end{array}$ \\
\hline $\begin{array}{l}\text { The consumed water during } \\
\text { the three meals of a week } \\
\text { day before raising the }\end{array}$ & 179 & 59.5307 & 17.24095 & $* 000$ \\
$\begin{array}{l}\text { environmental awareness } \\
\begin{array}{l}\text { The consumed water } \\
\text { during the three meals of }\end{array}\end{array}$ & 179 & 49.7542 & 12.41175 & $* 000$ \\
$\begin{array}{l}\text { a week day after raising the } \\
\text { environmental awareness }\end{array}$ & & & & \\
\hline
\end{tabular}

The sample of the study: Is consisted of 179 female students. They were distributed according the variables of the study as presented in Table 2 .

Experiment 2: The members of the sample were asked to measure the amount of the consumed water for kitchen purposes during the week days and during the weekend (as all members of the family usually eat together at the week end and so number of the dishes and other utensils will be more). After that they were asked to reduce the rate amount by reducing the amount of water going out of the tap while doing the washing up.

Measurements were done covering all the aspects of the study after the consumption. Those measurements in addition to the social variables related to the family and their residence formed the data base for this study.

Data was analyzed statically to find out the interrelationship between the consumed water as an independent variable and the other variables: number of members of the family, average age of the members, average income and number of the utensils, which form the dependent variables of the study.

The hypothesis of the study: This study was conducted to answer the following questions:

- Did the environmental awareness lead to the reduction of the consumed water in washing kitchen utensils

- What is the amount of the reduced water after raising environmental awareness

- What are the factors that reduced the amount of water consumption in washing kitchen utensils

\section{RESULTS}

The results showed the average of water consumption used for doing the washing kitchen utensils for the three meals during week days before raising environmental awareness was $59.5 \mathrm{~L} \mathrm{day}^{-1}$. This average was reduced to $49.5 \mathrm{~L} \mathrm{day}^{-1}$ after raising the awareness (Table 3).

Table 3 shows means of the water consumption for the three daily meals of the week day before and after raising environmental awareness less than 0.05 .

Also results of one way ANOVA related to the difference of water consumption in relation to the number of members of the family in week days and for the three meals before and after raising the degree of the environmental awareness showed that the means difference when family consisted of (2-5) members is 
(7.3) $\mathrm{L} \mathrm{day}^{-1}$, however this difference is raised to 10.4 $\mathrm{L} \mathrm{day}^{-1}$ when family members are (6-9). It has also increased to be $12 \mathrm{~L} \mathrm{day}^{-1}$ when family consisted of (1014) members (Table 4). These differences are found to be statistically significant at the statistical level 0.05 which assures that preceding finding.

Table 4 shows water consumption before and after raising the degree of awareness during the three meals of a week days in relation to the number of the family members.

Table 3: Means of the water consumption for the three daily meals of the week day before and after raising environmental awareness

\begin{tabular}{|c|c|c|c|}
\hline Family's person's category & Number & Frequency & Percent \\
\hline \multirow[t]{4}{*}{ Valid } & $2-5$ & 47 & 26.3 \\
\hline & $6-9$ & 111 & 62.0 \\
\hline & $10-14$ & 21 & 11.7 \\
\hline & Total & 179 & 100.0 \\
\hline \multicolumn{4}{|l|}{ Category of mean of the age } \\
\hline \multirow[t]{4}{*}{ Valid } & $15-22$ & 112 & 62.6 \\
\hline & $23-30$ & 54 & 30.2 \\
\hline & $31-40$ & 13 & 7.3 \\
\hline & Total & 179 & 100.0 \\
\hline \multicolumn{4}{|c|}{ Category of mean of the income (JD) } \\
\hline \multirow[t]{3}{*}{ Valid } & $200-600$ & 139 & 77.7 \\
\hline & $601-1000$ & 40 & 22.3 \\
\hline & Total & 179 & 100.0 \\
\hline
\end{tabular}

Table 4: Water consumption before and after raising the degree of awareness

\begin{tabular}{lclcl}
\hline $\begin{array}{l}\text { Family } \\
\text { person's } \\
\text { category }\end{array}$ & $\begin{array}{l}\text { Mean of water } \\
\text { consumption } \\
\text { L day }^{-1}\end{array}$ & $\begin{array}{l}\text { Std } \\
\text { deviation }\end{array}$ & Number & Sig. \\
\hline 5-Feb & 7.2553 & 4.69258 & 47 & 0.000 \\
9-Jun & 10.3964 & 9.76569 & 111 & 0.053 \\
14-Oct & 12.1429 & 9.94126 & 21 & \\
Total & 9.7765 & 8.84926 & 179 & \\
\hline
\end{tabular}

Table 5: Pairwise comparisons

\begin{tabular}{lllll}
\hline $\begin{array}{l}\text { (I) family's } \\
\text { category }\end{array}$ & $\begin{array}{l}\text { (J) family's } \\
\text { category }\end{array}$ & $\begin{array}{l}\text { Mean difference } \\
(\mathrm{I}-\mathrm{J})\end{array}$ & Std. error & Sig.(a) \\
\hline $2-5$ & $6-9$ & $-3.141\left(^{*}\right)$ & 1.523 & 0.041 \\
& $10-14$ & $-4.888\left(^{*}\right)$ & 2.297 & 0.035 \\
$6-9$ & $2-5$ & $3.141\left(^{*}\right)$ & 1.523 & 0.041 \\
& $10-14$ & -1.746 & 2.083 & 0.403 \\
$10-14$ & $2-5$ & $4.888\left(^{*}\right)$ & 2.297 & 0.035 \\
& $6-9$ & 1.746 & 2.083 & 0.403 \\
\hline
\end{tabular}

Based on estimated marginal means; *: The mean difference is significant at the 0.05 level; An Adjustment for multiple comparisons: Least significant difference (equivalent to no adjustments)

Table 6: The differences in water consumption (before and after raising environmental awareness) on the three meals of a week day in accordance to the age of the family members

\begin{tabular}{lclrl}
\hline Family's category & \multicolumn{1}{c}{ Mean } & Std. deviation & \multicolumn{1}{c}{$\mathrm{N}$} & Sig. \\
\hline Descriptive 15-22 & 10.5714 & 9.76731 & 112 & 0.287 \\
$23-30$ & 8.6111 & 7.59199 & 54 & 0.000 \\
$31-40$ & 7.7692 & 2.86222 & 13 & 0.287 \\
Total & 9.7765 & 8.84926 & 179 & \\
\hline$R^{2}=0.014$ (adjusted $\left.\mathrm{R}^{2}=0.003\right)$ & & &
\end{tabular}

$\mathrm{R}^{2}=0.014$ (adjusted $\mathrm{R}^{2}=0.003$ )
These differences of consumption were higher in families of members between (10-14). The differences for this group in addition to the other groups were significant at level 0.05 . This means that all the family groups have made use of this study.

In general the rate of water saving after raising the degree of the environmental awareness related to the reduction of the economical consumption of water for every family recalled $9.7 \mathrm{~L} \mathrm{day}^{-1}$ (Table 5).

As the age of family members decreased the amount of saved water decreased. For example, in group between (15-22) for a day was (10.6) $\mathrm{L} \mathrm{day}^{-1}$. It decreased to $9.6 \mathrm{~L} \mathrm{day}^{-1}$, the group between (23-30) and more reduced for the group age between (31-40) to become (7.7) $\mathrm{L} \mathrm{day}^{-1}$. In general the average rate of daily is saving after raising the degree of awareness in accordance to the age of the member of the family is $9 \mathrm{~L}$ daily. These differences in mean of the saving water are consumption is statistically significant at 0.0001 Table 6.

Consumption differences before and after raising environment awareness on the three day meals of a week day in accordance to the average age of the members of the family.

Also Table 6 showed that the differences in water consumption (before and after raising environmental awareness) on the three meals of a week day in accordance to the age of the family members is significant at (0.05).

\section{DISCUSSION}

In Table 7 the paired comparisons showed that the difference in consumption is the highest in family group aged between (15-22) years. However, this group represents about $60 \%$ of the sample of the study. The mean saving of the daily consumption was $10.6 \mathrm{~L} \mathrm{day}^{-1}$ after raising the degree of the environmental awareness. This indicates that the family of the less age has benefited more than the other family groups of this study. For this group it seems to acquire more positive behavior patterns than the groups of older age which seem to have acquired more negative behavior patterns.

Table 7: Pairwise comparisons

\begin{tabular}{lllll}
\hline $\begin{array}{l}\text { (I) mean } \\
\text { of age }\end{array}$ & $\begin{array}{l}\text { (J) 0020 mean } \\
\text { of age }\end{array}$ & $\begin{array}{l}\text { Mean difference } \\
\text { (I-J) }\end{array}$ & Std. error & Sig.(a) \\
\hline $15-22$ & $23-30$ & 1.960 & 1.464 & 0.182 \\
& $31-40$ & 2.802 & 2.589 & 0.281 \\
$23-30$ & $15-22$ & -1.960 & 1.464 & 0.182 \\
& $31-40$ & -842 & 2.730 & 0.758 \\
$31-40$ & $15-22$ & -2.802 & 2.589 & 0.281 \\
& $23-30$ & -.842 & 2.730 & 0.758 \\
\hline
\end{tabular}

Based on estimated marginal means; An Adjustment for multiple comparisons: Least significant difference 
Am. J. Applied Sci., 7 (8): 1123-1128, 2010

Table 8: Water consumption (before and after raising the degree of environmental awareness) of the three meals of the week day in accordance to the average income of the family

\begin{tabular}{lrrrl}
\hline Income & Mean & Std. deviation & N & Sig. \\
\hline $200-600$ & 8.8058 & 7.98811 & 139 & 0.000 \\
$601-1000$ & 13.1500 & 10.79779 & 40 & 0.006 \\
Total & 9.7765 & 8.84926 & 179 & \\
\hline
\end{tabular}

Table 9: Pairwise comparisons

\begin{tabular}{lllll}
\hline (I) income & $(\mathrm{J})$ income & $\begin{array}{l}\text { Mean difference } \\
(\mathrm{I}-\mathrm{J})\end{array}$ & Std. error & Sig.(a) \\
\hline $200-600$ & $601-1000$ & $-4.344(*)$ & 1.558 & 0.006 \\
$601-1000$ & $200-600$ & $4.344(*)$ & 1.558 & 0.006 \\
\hline The difference dependent variable: 1
\end{tabular}

Looking at the two preceding Table 8 and 9 of paired comparisons showed that the difference in consumption was the highest in family age group between $(15-22)(10.57 \mathrm{~L})$ after the training. While these differences in consumption of the family group age between (23-30) were only (8.61) L. The family age group between (31-40) has shown a difference (7.76). This indicates the families of the age between (15-22) are the best in making use of the training to preserve and save water to reduce water consumption than the family age group (32-30) and finally the family age group of (31-40).

Using this, there seems be a reversal relationship between the average of the family members' age and the average rate of water consumption for the daily use of the kitchen.

The average income of the family has also a strong effect on the average of water consumption used in washing and kitchen. The mean difference of consumption has reached $8.8 \mathrm{~L}$ daily for the family whose average income between (200-600 JD/month). This saving reaches to $13.2 \mathrm{~L}$ daily for the family whose average income is between (601-1000 JD/month.

These differences are of statistical significance at the level of significance (0.0001) Table 8 .

The pair wise comparison presented in Table 9 showed that the difference of consumption of the average income between (601-1000JD/month). This showed that this family group of the higher level of income has beneficiated of raising the environmental awareness to reduce water consumption. This might be a result of the financial ability of these families to win technological tools that help to reduce water consumption and having money and varied mass media techniques that help them to be acquainted with different environmental programs. This is why their environmental awareness can be increased more than the other families.

In general, the average daily saving in relation to the average family income is (11) $\mathrm{L}$ after raising the degree of the environmental awareness and being able to economically use water in doing the kitchen washing up.
Table 10: The relation between water consumption and number of utensils for three meals before raising environmental awareness

\begin{tabular}{|c|c|c|c|}
\hline & & $\begin{array}{l}\text { Number of } \\
\text { utensils } 1\end{array}$ & $\begin{array}{l}\text { Water } \\
\text { consumption } \\
0.674(* *)\end{array}$ \\
\hline The number of & Pearson correlation & & 0000 \\
\hline $\begin{array}{l}\text { day for three meals, } \\
\text { before raising } \\
\text { environmental a } \\
\text { wareness }\end{array}$ & $\mathrm{N}$ & 179.000 & 179.000 \\
\hline $\begin{array}{l}\text { Water consumption } \\
\text { raising the }\end{array}$ & $\begin{array}{l}\text { Pearson correlation } \\
\text { Sig. (2-tailed) }\end{array}$ & $\begin{array}{l}0.674(* *) \\
0.000\end{array}$ & 1.000 \\
\hline $\begin{array}{l}\text { environmental } \\
\text { awareness }\end{array}$ & $\mathrm{N}$ & 179.000 & 179.000 \\
\hline
\end{tabular}

Table 11: The relation between water consumption and number of utensils for three meals after raising environmental awareness

\begin{tabular}{llcr}
\hline & & \multicolumn{1}{c}{$\begin{array}{c}\text { Number } \\
\text { of utensils }\end{array}$} & $\begin{array}{l}\text { water } \\
\text { consumption }\end{array}$ \\
\hline $\begin{array}{l}\text { The number of utensils } \\
\text { in a week day for three } \\
\text { meals, after raising } \\
\text { environmental awareness }\end{array}$ & $\begin{array}{l}\text { Pearson } \\
\text { correlation }\end{array}$ & 1.000 & $0.801(* *)$ \\
& Sig. (2-tailed) & & \\
& $\mathrm{N}$ & 179.000 & 179.000 \\
$\begin{array}{l}\text { Water consumption after } \\
\text { raising the environmental } \\
\text { awareness }\end{array}$ & $\begin{array}{l}\text { Pearson } \\
\text { correlation }\end{array}$ & $0.801(* *)$ & 1.000 \\
& Sig. (2-tailed) & 0.000 & \\
& $\mathrm{~N}$ & 179.000 & 179.000 \\
\hline
\end{tabular}

**: Correlation is significant at the 0.01 level (2-tailed)

On the other hand, the results of statistical analysis especially the correlation values between he numbers of the used utensils for the three meals and the amount of the consumed water for doing the washing is a progressive relationship for the positive coefficient value is 0.67 with a trusting degree 0.99 before raising the degree of environmental awareness.

This positive coefficient increased after raising the degree of the environmental awareness to be 0.81 and with a trusting value (0.99) Table 10.

This means that the number of the utensils used for having meals is so significant and the most effective in reducing the consumption of water for kitchen use.

It is noticed from the previous Table 10 that there is a positive relationship between the amount of the water consumption and the number of the utensils used for the three meals of the week day before raising environmental awareness. But this relation increased after raising environment awareness (Table 11).

The findings of the study: Raising the degree of the environmental awareness in relation to the importance of water and its economic consumption contributes to the reduction of the amount of the consumed water to 
wash the food and kitchen utensils of the family with an average about $9.9 \mathrm{~L} \mathrm{day}^{-1}$ i.e., about $10 \mathrm{~L}$ daily.

Raising environmental awareness lead to positive effects for the young age groups more than the older age groups in relation to preserving water consumption and using it economically.

The average of the consumption of water for washing the food and kitchen utensils is affected by many different variables: The number of the family members, the average age of the family members, the level of the monthly income and the number of the utensils used for preparing and having the meals by the family.

\section{CONCLUSION}

Using these finding, this study recommends the following:

- Reviving some of the social habits of the Jordanian society like having the daily meals together which will lead to the reduction of the number of the used utensils

- Table 11 shows concentrating the attention of the environmental awareness programs on the young age groups mostly because they are the future makers. In relation to preserving the environmental resources keeping them hygienic and trying to extend their usability for the life long

- Using the cartoon dishes but by making sure to get rid of them properly so as not to affect the environment

- Taking steps by the government to decrease the expense of the technological tools that can be used to reduce water consumption so as to make them available for most Jordanian families regardless of the level of their income

- Generalize such environmental studies on all Jordanian families and their servants to increase the effect of their application

- $\quad$ Conducting more research and applied field studies in the area of the economical use of water for domestic purposes

\section{REFERENCES}

Hadjer, K., T. Klein and M. Schopp, 2005. Water consumption embedded in its social context, NorthWestern Benin. Phys. Chem. Earth Part A/B/C, 30: 357-364. DOI: 10.1016/j.pce.2005.06.014

Rosegrant, M.W., X. Cai and S.A. Cline, 2002. Water and food to 2025. International Food Policy Research Institute. http://ideas.repec.org/p/fpr/issbrf/13.html

Oliver, W.T., 1990. Water awareness project. USADand Jordanian Environment Society.

Otaki, Y., M. Otaki, P. Pengchai, Y. Ohta and T. Aramaki, 2008. Micro-components survey of residential indoor water consumption in Chiang Mai, drink. Water Eng. Sci., 1: 17-25. http://www.drink-watereng-sci.net/1/17/2008/dwes-1-17-2008.pdf

Othman, A.M., 2008. Design of economical equipment for water and fuel level detection in Jordan. Am. J. Applied Sci., 5: 473-478. http://www.scipub.org/fulltext/ajas/ajas55473-478.pdf

Tarawneh, Z.S., N.A. Hadadin and A.N. Bdour, 2008. Policies to enhance water sector in Jordan. Am. J. Applied Sci., 5: 698-704. http://www.scipub.org/fulltext/ajas/ajas56698-704.pdf

Venot, J.P., F. Molle and R. Courcier, 2006. Dealing with closed basins: The case of the lower Jordan River Basin. World Water Week. http://www.iwmi.cgiar.org/assessment/files_new/p ublications/Workshop\%20Papers/WWW_2006_F Molle.pdf 